\title{
PREOPERATIVE HALO-GRAVITY TRACTION WITH AND WITHOUT ANTERIOR RELEASE FOR SEVERE SCOLIOSIS
}

\author{
TRACÇÃO HALOGRAVITACIONAL COM E SEM LIBERTAÇÃO ANTERIOR NO TRATAMENTO \\ DE ESCOLIOSE GRAVE
}

\section{TRACCIÓN PREOPERATORIA DE HALO-GRAVEDAD CON Y SIN LIBERACIÓN ANTERIOR EN ESCOLIOSIS GRAVE}

\author{
Andreia Mercier Nunes, ${ }^{1}$ Nuno Correia Mendonça, ${ }^{2}$ Jorge Mineiro, ${ }^{3}$ João Lameiras Campagnolo ${ }^{3}$ \\ 1. Centro Hospitalar de Lisboa Ocidental, Orthopedics and Traumatology Service, Lisbon, Portugal. \\ 2. Hospital Dr. Fernando da Fonseca, Orthopedics and Traumatology Service, Amadora, Portugal. \\ 3. Hospital Dona Estefânia, Children's Orthopedic Service, Lisbon, Portugal.
}

\begin{abstract}
Objective: This study aims to compare the use of halo-gravity traction (HGT) with and without previous anterior release, in terms of curve reduction, for the treatment of pediatric severe spinal deformity. Methods: From 2010 to 2016, all patients treated with HGT prior to instrumentation for scoliosis and kyphoscoliosis were reviewed. They were assessed by deformity etiology, previous anterior release, instrumentation procedure used, traction protocol, major Cobb angle before traction, after the protocol, and after the instrumentation procedure. Twelve patients met these criteria and constituted the sample groups: Group I $(n=7)$ with anterior release and Group II ( $n=5)$ without anterior release. Results: The average pre-traction major curve Cobb angles were $114.9^{\circ}$ and $108.4^{\circ}$ for Group I and II, respectively (P>0.05). After HGT, both groups achieved a significant reduction in curve angle $(\mathrm{P}<0.05)$. Group I presented an average Cobb angle of $95.0^{\circ}$ after $\mathrm{HGT}$, representing a $17.3 \%\left(19.8^{\circ}\right)$ curve reduction. Group II presented a Cobb angle of $80.1^{\circ}$, representing a $25.2 \%\left(28.4^{\circ}\right)$ curve reduction. The difference between the two groups in relation to the reduction of major curve after HGT was not statistically significant $(\mathrm{P}=0.073)$. After the surgical procedure, the correction achieved was significantly improved $(P<0.05)$, without statistically significant difference between the two groups $(P>0.05)$. No major HGT related complications were reported. Conclusions: Anterior release prior to HGT did not increase major curve correction after posterior surgery for severe pediatric idiopathic and syndromic scoliosis. HGT is an effective and safe technique, though it frequently presents minor and transitory complications. Level of Evidence III; Retrospective Comparative Study.
\end{abstract}

Keywords: Traction; Diskectomy; Scoliosis, Pediatrics.

\section{RESUMO}

Objetivo: O presente estudo tem como objectivo comparar a utilização de tracção halo-gravitacional (THG), com e sem libertações anteriores prévias, no que diz respeito à correcção da curva no tratamento de escoliose grave pediátrica. Métodos: Foram avaliados retrospectivamente doentes com escoliose/cifoescoliose, tratados com THG prévia ao procedimento instrumentado, entre 2010 e 2016. Foi avaliada a etiologia da deformidade, realização de libertações discais prévias, tipo de procedimento instrumentado, protocolo da THG, ângulo de Cobb da curva major previamente à THG, após protocolo e após procedimento instrumentado. Doze doentes satisfaziam os critérios de inclusão: Grupo I ( $n=7)$ com libertações anteriores prévias e Grupo II $(n=5)$ sem libertações prévias. Resultados: O ângulo Cobb médio da curva major era 114,9 e 108, $4^{\circ}$ para o Grupo I e /l respectivamente $(P>0,05)$. Após THG, ambos os grupos apresentaram redução significativa da curva major ( $P<0,05)$. O Grupo I apresentava um ângulo Cobb médio de 95,0 , representando redução de 17,3\% $\left(19,8^{\circ}\right)$. O Grupo II apresentava um ângulo Cobb médio de $80,1^{\circ}$, representando redução de 25,2\% $\left(28,4^{\circ}\right)$. Após THG não existiu diferença significativa entre os grupos, no que diz respeito à redução da curva major $(P=0,073)$. Após instrumentação, a correcção aumentou de forma significativa $(P<0,05)$, sem diferença estatisticamente significativa entre os dois grupos $(P=0.05)$. Não existiram complicações major relacionadas com a THG. Conclusões: Libertações discais prévias à THG não parecem aumentar a correcção final da curva major, no tratamento de escoliose pediátrica grave. A THG é um método efectivo e seguro. Nível de Evidência III; Estudo Retrospectivo Comparativo.

Descritores: Tração; Discotomia; Escoliose; Pediatria.

\section{RESUMEN}

Objetivo: Este estudio tiene como objetivo comparar el uso de la tracción de halo-gravedad (THG) con y sin liberación anterior previa, con respecto a la reducción de la curva en el tratamiento de la deformidad espinal pediátrica grave. Métodos: Entre 2010 y 2016, se revisaron todos los pacientes tratados con THG antes de la instrumentación para escoliosis y cifoescoliosis. Se evaluaron por etiología de la deformidad, liberación anterior previa, tipo de instrumentación, protocolo de tracción, ángulo de Cobb mayor antes de la tracción, después del protocolo y después de la instrumentación. Doce pacientes cumplieron los criterios de inclusión y constituyeron los grupos de muestra: Grupo I $(n=7)$ con liberación anterior y Grupo II $(n=5)$ sin liberación anterior. Resultados: El promedio de los ángulos de Cobb de la curva principal antes de la tracción fue de $114,9^{\circ}$ y 108, $4^{\circ}$ para el grupo I y ll, respectivamente (P > 0,05). Después de la THG, ambos grupos lograron una reducción significativa en el ángulo de la curva $(P>0,05)$. El Grupo I tenía ángulo Cobb promedio de $95^{\circ}$, después

Work conducted at Hospital Dona Estefânia, Children's Orthopedic Service, Lisbon, Portugal.

Correspondence: Andreia Mercier Nunes. Centro Hospitalar de Lisboa Ocidental, Serviço de Ortopedia e Traumatologia. Estrada do Forte do Alto do Duque, $1449-005$ Lisboa, Portugal. andreia.mercier.nunes@gmail.com 
de la THG, lo que representa una reducción de la curva del 17,3\% (19,8\%). El Grupo II tenía ángulo de Cobb de 80,10, que representa una reducción de la curva del $25,2 \%\left(28,4^{\circ}\right)$. La diferencia entre los dos grupos en relación con la reducción de la curva principal después de la THG no fue estadísticamente significativa $(P=0.073)$. Después del procedimiento quirúrgico, la corrección mejoró de manera expresiva $(P>0,05)$, aunque sin diferencia estadísticamente significativa entre los dos grupos $(P>0,05)$. No se informaron complicaciones mayores relacionadas con la THG. Conclusiones: La liberación anterior previa a la THG no aumentó la corrección de la curva principal después de la cirugía posterior para la escoliosis pediátrica idiopática y sindrómica grave. La THG es una técnica efectiva y segura, aunque con frecuencia presenta complicaciones menores y transitorias. Nivel de Evidencia III; Estudio Retrospectivo Comparativo.

Descriptores: Tracción; Discectomía; Escoliosis; Pediatría.

\section{INTRODUCTION}

Pediatric severe spinal deformity remains a surgical challenge, with high morbidity and mortality rates. ${ }^{1}$ Besides being technically difficult, acute correction of a rigid curve increases the risk of neurologic injury and pseudoarthrosis. ${ }^{2}$

Spine surgeons have been trying to find a method to achieve a more gradual reduction of the curve prior to definitive fusion. These methods include temporary internal distraction, anterior release, halo-femoral traction, and halo-gravity traction (HGT). ${ }^{1}$

Pre-operative HGT has been shown to allow a gradual curve reduction with continuous neurological monitoring (patient awake) and a low rate of related complications. Some authors report that HGT can even improve preoperative nutritional status and pulmonary function. ${ }^{3}$

It has also been reported that anterior release with disc excision only slightly increased spinal flexibility. ${ }^{4}$

However, the use of HGT without previous anterior or posterior release, as well as the optimal traction protocol, is still in dispute. ${ }^{2,3}$

The purpose of the present study is to compare the use of HGT with and without previous anterior release, in terms of curve reduction.

\section{METHODS}

Data

From 2010 to 2016, all patients treated with HGT prior to instrumentation for scoliosis and kyphoscoliosis at a single Pediatric Hospital were reviewed.

Only proximal thoracic, main thoracic, or severe thoracolumbar (>90 degrees) spinal deformities were included. Patients with missing radiographic data (standing anteroposterior radiograph pre-HGT at the completion of traction and after final surgical correction) or clinical data were excluded.

Data were retrospectively collected from clinical records and evaluated by one of the authors, who was not involved in the patients' treatment. They were assessed by age, gender, etiology of the deformity, previous anterior release and instrumentation procedure. We also assessed patients' weight, maximum traction weight and time, major curve Cobb angle before traction, after completion of traction, and after the instrumentation procedure. The daily clinical evaluations to monitor neurological or halo-related complications were also assessed.

Each Cobb measurement is the average of three individual measurements.

Twelve patients met these criteria and constituted the sample groups: Group I $(n=7)$ with anterior release and Group II $(n=5)$ without anterior release.

Database management ensured patient anonymity and confidentiality, and fully complied with the Caldicott principles. As this is a retrospective study, it was not submitted to the Ethics Committee, and there was no informed consent form.

\section{Surgical treatment protocol}

\section{Group I: Halo-gravitational protocol with anterior release}

The patients were submitted to the anterior thoracic or thoracophrenic approach by lumbotomy and discectomies (3-4 levels) at the curve apex and halo placement. Six to eight pins were placed perpendicular to the skull and tightened using a torque wrench. Traction started immediately, with a low amount of weight (usually $2.5 \mathrm{~kg}$ ).
A daily increment of $0.5 \mathrm{~kg}$ was expected, depending on patients tolerance. Upright overhead traction via a traction bale attached to a wheelchair was used as soon as the patients were able to stand. Dysphagia and neck pain were an indication to stop increasing the traction weight, while neurological signs were an indication to decrease the traction weight. The nursing care of these patients included daily alcoholic cleaning of the pins.

\section{Group II: Halo-gravitational protocol without anterior release}

As described for the protocol with anterior release, all patients were taken to the theatre for the halo placement and the traction was started immediately with a low amount of weight. The daily weight increases; ambulation and serial radiographs were as described above.

For both group of patients, an on traction scoliogram was taken after the instrumentation procedure.

\section{Statistical analysis}

Patient demographics, pre-traction Cobb angle and traction protocol (time and maximum traction weight) were

compared between treatment groups to ensure comparability.

Fisher's exact test was used to evaluate differences between proportions. Once the normality assumptions were met, the unpaired Student's t-test was performed to evaluate differences between means and Mann-Whitney $U$ test to evaluate differences between medians.

All tests were conducted in 95\% confidence interval, with statistical significance adjusted to a p value of 0.05 or below. All analyses were performed using SPSS version 22.0 (IBM Corp., Armonk, NY).

\section{RESULTS}

A total of 12 patients were included in the analysis, 7 underwent anterior release previous to HGT and 5 did not. The average age at the time of HGT was 13.8 years. Ten patients were female and 2 male. The diagnoses in Group I were 4 cases of idiopathic scoliosis and 3 of syndromic kyphoscoliosis/scoliosis; in Group II, there were 2 cases of idiopathic scoliosis, 2 syndromic and 1 thoracogenic (Table 1).

The duration of traction time before surgery range from 26 to 48 days, and averaged at 35.3 days. The average of the maximum traction weight applied was $40.5 \%$ of the body weight (ranging from 30.3 to $51.3 \%$ ) (Table 2).

Regarding the previous variables, no significant difference was found between Group I and II (P>0.05) (Table 3).

\section{Radiograph measurements}

The average pre-traction major curve Cobb angle was $114.9^{\circ}$ and $108.4^{\circ}$ for Groups I and II respectively $(\mathrm{P}>0.05)$.

After HGT, both groups suffered a significant major curve reduction $(\mathrm{P}<0.05)$.

The group with previous release presented an average Cobb angle of $95.0^{\circ}$ after HGT, representing a $17.3 \%\left(19.8^{\circ}\right)$ curve reduction. The group without previous release presented a Cobb angle of $80.1^{\circ}$, representing a $25.2 \%\left(28.4^{\circ}\right)$ curve reduction. The difference between the two groups in terms of major curve reduction after HGT was not statistically significant $(P=0.073)$.

After the surgical procedure, the correction achieved was significantly improved in both groups $(P<0.05)$. For Group I, an average 
further correction of $30.6 \%\left(33.4^{\circ}\right)$ was achieved, with a final average Cobb angle of $61.1^{\circ}$ (46.9\% total correction). For Group II the surgical procedure resulted in $18.4 \%\left(19.2^{\circ}\right)$ further correction, with a final average Cobb angle of $60.9^{\circ}$ (43.7\% total correction). No statistically significant difference was found between the two groups in regard to the average Cobb angle after surgery $(P>0.05)$.

\section{Complications}

No major HGT related complications were reported during the treatment of these patients.

One patient underwent halo revision to achieve better positioning. In three patients, the weight increments had to be delayed due to dysphagia (1) and neck pain (2). The symptoms were then reverted and the protocol resumed without further complications. We report an overall complication rate of $33.3 \%$.

Table 1. Descriptive data

\begin{tabular}{|c|c|c|c|c|c|}
\hline Patient & $\begin{array}{c}\text { Age } \\
\text { (years) }\end{array}$ & Sex & Etiology & $\begin{array}{l}\text { Anterior } \\
\text { release }\end{array}$ & $\begin{array}{c}\text { Instrumentation } \\
\text { Procedure }\end{array}$ \\
\hline 1 & 18 & $\mathrm{~F}$ & $\begin{array}{c}\text { Syndromic } \\
\text { kyphoscoliosis } \\
\text { (polymorphic } \\
\text { syndrome) }\end{array}$ & Y & Fusion \\
\hline 2 & 7 & $\mathrm{~F}$ & $\begin{array}{c}\text { Syndromic } \\
\text { kyphoscoliosis } \\
\text { (neurofibromatosis) }\end{array}$ & Y & Growing Rods \\
\hline 3 & 16 & $\mathrm{~F}$ & $\begin{array}{c}\text { Juvenile idiopathic } \\
\text { scoliosis }\end{array}$ & Y & Fusion \\
\hline 4 & 15 & $\mathrm{~F}$ & \begin{tabular}{|c|}
$\begin{array}{c}\text { Adolescent idiopathic } \\
\text { scoliosis }\end{array}$ \\
\end{tabular} & Y & Fusion \\
\hline 5 & 13 & $\mathrm{~F}$ & \begin{tabular}{|c|} 
Adolescent idiopathic \\
scoliosis
\end{tabular} & Y & Fusion \\
\hline 6 & 16 & $\mathrm{~F}$ & $\begin{array}{l}\text { Syndromic scoliosis } \\
\text { (polymorphic } \\
\text { syndrome) }\end{array}$ & Y & Fusion \\
\hline 7 & 16 & M & $\begin{array}{c}\text { Infantile idiopathic } \\
\text { scoliosis }\end{array}$ & $\mathrm{Y}$ & Fusion \\
\hline 8 & 14 & $\mathrm{~F}$ & $\begin{array}{c}\text { Idiopathic } \\
\text { kyphoscoliosis }\end{array}$ & $\mathrm{N}$ & Fusion \\
\hline 9 & 5 & $\mathrm{~F}$ & \begin{tabular}{|c|}
$\begin{array}{c}\text { Syndromic scoliosis } \\
\text { (Marfan) }\end{array}$ \\
\end{tabular} & $\mathrm{N}$ & Growing Rods \\
\hline 10 & 16 & $\mathrm{M}$ & Thoracogenic scoliosis & $\mathrm{N}$ & Fusion \\
\hline 11 & 13 & $\mathrm{~F}$ & $\begin{array}{c}\text { Syndromic } \\
\text { kyphoscoliosis } \\
\text { (neurofibromatosis) }\end{array}$ & $\mathrm{N}$ & Fusion \\
\hline 12 & 15 & $\mathrm{~F}$ & $\begin{array}{c}\text { Adolescent idiopathic } \\
\text { scoliosis }\end{array}$ & $\mathrm{N}$ & Fusion \\
\hline
\end{tabular}

\section{DISCUSSION}

HGT is a time-tested orthopedic technique that is useful for obtaining correction prior to operative treatment, as well as for delaying the early onset of deformities. . $, 7,3,8,9^{-1}$

As severe pediatric spinal deformities remain a challenge, different combinations of techniques are still being tested. The combination of anterior disc release with HGT is believed to increase spinal flexibility and therefore improve correction following posterior surgery. ${ }^{10}$ However, the real effect of anterior release in spinal flexibility, particularly in achieving a better curve correction, is still controversial. ${ }^{4}$

Among the severe spinal deformities, HGT alone appears to be an effective and less invasive technique that is well-tolerated and with a low rate of major complications. ${ }^{3}$ Therefore many recent studies have attempted to evaluate the correction attributable to HGT alone. ${ }^{2,3,7}$ To the best of our knowledge, there are no reports on the comparison between HGT alone and its combination with anterior release for the treatment of idiopathic and syndromic severe scoliosis.

Using a standardized traction protocol allowed us to compare patients with and without previous release. No significant differences were found regarding the final major coronal curve correction (46.9\% versus 43.7\%). However, the reduction achieved after the traction protocol, though without statistical significance $(P=0.073)$, was higher in the group of patients without release, $28.4^{\circ}$ versus $19.8^{\circ}$. The authors believe this is partly due to a greater tolerance

Table 3. Comparative data.

\begin{tabular}{|c|c|c|c|}
\hline Patient & $\begin{array}{c}\text { Group I } \\
\text { (With previous } \\
\text { release) }\end{array}$ & $\begin{array}{c}\text { Group II } \\
\text { (Without } \\
\text { previous release) }\end{array}$ & $\mathbf{P}$ \\
\hline Age & 14.43 & 12.80 & 0.501 \\
\hline Sex & & & 0.793 \\
\hline Female & 6 & 4 & \\
\hline Male & 1 & 1 & \\
\hline $\begin{array}{c}\text { Maximum Traction } \\
\left(\% \mathrm{BW}^{1}\right)\end{array}$ & 40.63 & 40.31 & 0.928 \\
\hline Traction Time (days) & 36.00 & 34.40 & 0.734 \\
\hline Cobb PreT ${ }^{2}$ & 114.88 & 108.43 & 0.492 \\
\hline Cobb Post $T^{3}$ & 95.04 & 80.06 & 0.073 \\
\hline Cobb $\mathrm{PO}^{4}$ & 61.10 & 60.88 & 0.983 \\
\hline 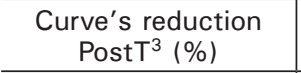 & 17.29 & 25.25 & 0.147 \\
\hline $\begin{array}{c}\text { Curve's reduction } \mathrm{PO}^{4} \\
(\%)\end{array}$ & 46.89 & 43.68 & 0.695 \\
\hline
\end{tabular}

Table 2. Traction related data.

\begin{tabular}{|c|c|c|c|c|c|c|c|c|c|}
\hline Patient & $\begin{array}{l}\text { Anterior } \\
\text { release }\end{array}$ & $\begin{array}{l}\text { BW } 1 \\
(\mathrm{~kg})\end{array}$ & $\begin{array}{c}\text { Maximum Traction } \\
\text { (\%BW) }\end{array}$ & $\begin{array}{l}\text { HGT Time } \\
\text { (day) }\end{array}$ & $\begin{array}{l}\text { Cobb } \\
\text { PreT }^{2} \\
\end{array}$ & $\begin{array}{l}\text { Cobb } \\
{\text { Post } \mathrm{T}^{3}}\end{array}$ & $\begin{array}{c}\text { Cobb } \\
\mathrm{PO}^{4}\end{array}$ & \begin{tabular}{|c|}
$\begin{array}{c}\text { Curve's reduction } \\
\text { Post }^{3}(\%)\end{array}$ \\
\end{tabular} & $\begin{array}{c}\text { Curve's reduction } \\
\mathrm{PO}^{4}(\%)\end{array}$ \\
\hline 2 & $\mathrm{Y}$ & 23 & 34.8 & 28 & 137.0 & 118.7 & 78.2 & 13.3 & 42.9 \\
\hline 4 & $\mathrm{Y}$ & 39 & 51.3 & 35 & 116.8 & 99.2 & 42.2 & 15.1 & 63.9 \\
\hline 5 & $\mathrm{Y}$ & 40 & 45.0 & 42 & 102.9 & 88.1 & 49.2 & 14.4 & 52.2 \\
\hline 6 & $\mathrm{Y}$ & 38 & 38.2 & 28 & 109.7 & 78.5 & 48.0 & 28.4 & 56.2 \\
\hline 9 & $\mathrm{~N}$ & 15 & 43.3 & 34 & 137.5 & 99.8 & 89.6 & 27.4 & 34.9 \\
\hline 10 & $\mathrm{~N}$ & 44 & 40.9 & 26 & 91.5 & 75.5 & 43.5 & 17.4 & 52.5 \\
\hline 11 & $\mathrm{~N}$ & 30 & 43.3 & 48 & 90.1 & 77.8 & 71.1 & 13.6 & 21.0 \\
\hline 12 & $\mathrm{~N}$ & 46 & 37.0 & 35 & 109.7 & 83.0 & 54.0 & 24.3 & 50.8 \\
\hline Mean & - & - & $40.5 \%$ & 35.3 & 112.2 & 88.8 & 61.0 & 20.6 & 45.5 \\
\hline
\end{tabular}


to early ambulation in the group without release. On the other hand, the average Cobb angle before HGT was slightly higher in the Group I. This can be associated with more rigid curves, and therefore, a slightly poorer response to the HGT.

As mentioned in previous studies, finding the correct protocol in terms of time and traction weight is still a challenge. ${ }^{2}$ We used an average traction weight of $40.5 \%$ of the body weight for 35.3 days. A recent meta-analysis reported that traction weight in several studies can range from $30 \%$ to $50 \%$ of the body weight, from 2 to 12 weeks. ${ }^{3,9}$ Though more evidence is still needed, most of the correction can be expected to occur in the first 2 to 4 weeks. ${ }^{2,11,3}$ Length and traction weight still depend on various factors, such as patient tolerance and gradual curve correction.

HGT has a reported rate of complications of around $22 \%$, most of them non-severe or transitory. 2,3 The most common complication is related to the pins, such as loosening or infection.

Neurological complications are much rarer, even when compared with other traction techniques such as halo-femoral or halo-pelvic traction. $^{2}$ In our cohort, only minor complications occurred, and these were all completely resolved without affecting the traction protocol or the final outcome.

\section{CONCLUSION}

Anterior disc release prior to HGT does not increase major curve correction after posterior surgery for severe pediatric idiopathic and syndromic scoliosis. HGT is an effective and safe technique, though it frequently presents minor and transitory complications. Optimization of the HGT protocol is important, to achieve the best pre-operative correction while reducing the rate of complications.

All authors declare no potential conflict of interest related to this article.

CONTRIBUTION OF THE AUTHORS: Each author made significant individual contributions to this manuscript. All authors made substantial contributions to the concept and design, and/or acquisition of the data, and/or analysis and interpretation of data; all authors participated in drafting the article or revising it critically for important intellectual content; and gave final approval of the version to be submitted, and any revised versions. AMN (0000-0003-4229-4986); NCM (0000-0002-1649-9120); JM (0000-0001-6471-9688); JLC (0000-0003-1246-119X).. *ORCID (Open Researcher and Contributor ID).

\section{REFERENCES}

1. Nemani VM, Kim HJ, Bjerke-kroll BT, Yagi M, Pellise F, Nguyen JT, et al. Preoperative Halo-Gravity Traction for Severe Spinal Deformities at an SRS-GOP Site in West Africa. Spine 2015;40:153-161.

2. Bogunovic L, Lenke LG, Bridwell KH, Luhmann SJ. Preoperative Halo-Gravity Traction for Severe Pediatric Spinal Deformity: Complications, Radiographic Correction and Changes in Pulmonary Function. Spine Deformity 1 2013;33-39

3. Yang $\mathrm{C}$, Wang $\mathrm{H}$, Zheng Z, Zhang Z. Halo-gravity traction in the treatment of severe spinal deformity: a systematic review and meta-analysis. Euro Spine J 2017;26(7):1810-1816

4. Hempfing A, Ferraris L, Koller $\mathrm{H}$, Rump J, Metz-Stavenhagen $\mathrm{P}$. Is anterior release effective to increase flexibility in idiopathic thoracic scoliosis? Assessment by traction films. Eur Spine J. 2007;16(4):515-20.

5. Pourtaheri S, Shah SA, Ditro CP, Holmes L, Mackenzie WG. Preoperative halo-gravity traction with and without thoracoscopic anterior release for skeletal dysplasia patients with severe kyphoscoliosis. J Child Orthop. 2016;10:135-142.
6. B.A. Akbarnia et al. The Growing Spine: Management of Spinal Disorders in Young Children: Halo-Gravity Traction. 2016;537-51.

7. Mehlman CT, Al-Sayvad MJ, Crawford AH. Effectiveness of spinal release and halo-femoral traction in the management of severe spinal deformity. J Pediatr Orthop. 2004;24(6):667-73.

8. Ciu Y, Liu Z, Zhu F, Wang B, Yu Y, Zhu Z, et al. Comparison of effectiveness of Halo-femoral traction after anterior spinal release in severe idiopathic and congenital scoliosis: a retrospective study. J Orthop Surg Res. 2007:2:23.

9. Watanabe K, Lenke LG, Bridwell KH, Kim YJ, Hensley M, Koester L. Efficacy of perioperative halo-gravity traction for treatment of severe scoliosis $\left(\leq 100^{\circ}\right)$. J Orthop Sci. 2010:15(6):720-30

10. Arlet $\mathrm{V}$. Anterior thoracoscopic spine release in deformity surgery: a meta-analysis and review. Eur Spine J. 2000;9 Suppl 1:S17-23.

11. Park DK, Braaksma B, Hammerberg KW, Sturm P. The efficacy of preoperative halo-gravity traction in pediatric spinal deformity the effect of traction duration. J Spinal Disord Tech. 2013;26(3):146-54 